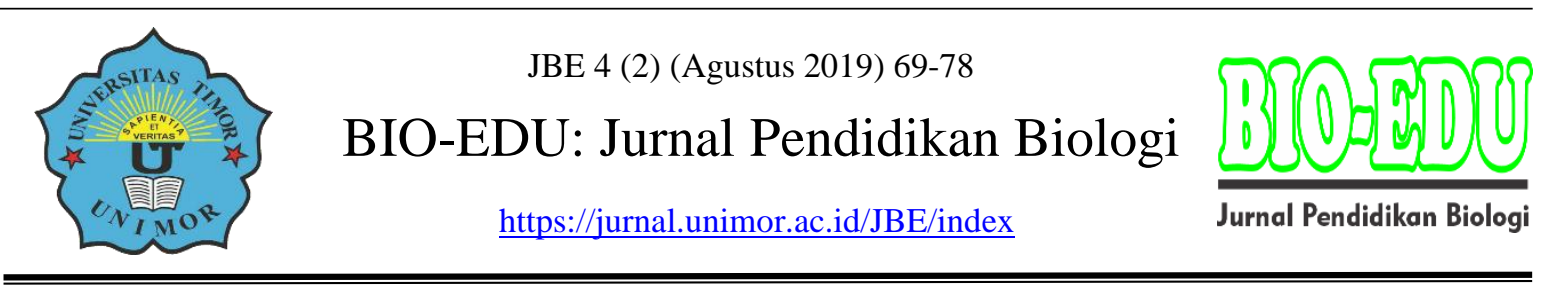

\title{
Pengaruh Model Pembelajaran Inkuiri Terbimbing dengan Mind Map \& Kooperatif Tipe TGT terhadap Pemahaman Konsep Siswa
}

\author{
Maria Paulin Saridewi \\ Program Studi Pendidikan Biologi, Universitas Timor \\ Email: dewiarkian8@gmail.com
}

DOI: https://doi.org/10.32938/jbe.v4i2.388

\begin{abstract}
Abstrak
Pembelajaran abad 21 lebih menekankan pada konsep student centered learning, sehingga pembelajaran yang dilaksanakan lebih bermakna bagi siswa, karena siswa dituntut tidak hanya mengerjakan tugas tetapi juga memahami konsep-konsep penting. Akan tetapi, masalah yang kini dihadapi adalah masih rendahnya pemahaman konsep siswa. Salah satu penyebabnya adalah metode mengajar guru yang masih bersifat konvensional. Model pembelajaran yang dipilih untuk memperbaiki pemahaman konsep siswa adalah inkuiri terbimbing dengan mind map dan kooperatif tipe TGT. Tujuan penelitian ini yaitu untuk melihat pengaruh model pembelajaran inkuiri terbimbing dengan mind map dan kooperatif tipe TGT terhadap pemahaman konsep siswa. Subjek dalam penelitian ini adalah siswa kelas VII SMPK St. Yoseph Noelbaki. Data hasil penelitian dianalisis dengan analisis varians satu arah dan deskriptif. Hasil penelitian menunjukkan terdapat pengaruh penerapan model pembelajaran inkuiri terbimbing dengan mind map dan kooperatif tipe TGT terhadap pemahaman konsep siswa, dengan nilai probabilitas (sig.) 0,01 lebih kecil dari nilai alpha yaitu 0,05.
\end{abstract}

Kata kunci : inkuri terbimbing, mind map, model pembelajaran kooperatif tipe Teams Games Tournament (TGT)

\begin{abstract}
$21^{\text {st }}$ century learning emphasizes the concept of student centered learning, so that learning is more meaningful for students, because students are required not only to do the task but also to understand important concepts. However, the problem now faced is the still low understanding of students' concepts. One reason is the teacher teaching method that is still conventional. The learning model that is considered to improve students' conceptual understanding is guided inquiry with mind map and cooperative type TGT. The purpose of this study is to see the effect of guided inquiry learning model with mind map and cooperative type TGT on understanding students' concepts. The subjects in this study were seventh grade students of SMPK St. Yoseph Noelbaki. The data of the research results were analyzed by analysis of one-way variance and descriptive. The results showed that there was an effect of the implementation of a guided inquiry learning model with mind map and cooperative TGT type on students' conceptual understanding, with a probability value (sig.) Of 0.01 smaller than the alpha value of 0.05 .
\end{abstract}

Keywords: guided inkuri, mind map, cooperative learning model type Teams Games Tournament (TGT) 


\section{PENDAHULUAN}

Negara Indonesia kini tengah menjalani pendidikan nasional abad 21. Pendidikan Nasional abad 21 bertujuan untuk mewujudkan cita-cita bangsa, yaitu masyarakat bangsa Indonesia yang sejahtera dan bahagia, dengan kedudukan yang terhormat dan setara dengan bangsa lain dalam dunia global, melalui pembentukan masyarakat yang terdiri dari sumber daya manusia yang berkualitas, yaitu pribadi yang mandiri, berkemauan dan berkemampuan untuk mewujudkan cita-cita bangsanya (BSNP dalam Sopian, 2016).

P21 (Partnership for 21st Century Learning) mengembangkan framework pembelajaran di abad 21 yang menuntut siswa untuk memiliki keterampilan, pengetahuan dan kemampuan di bidang teknologi, media dan informasi, keterampilan pembelajaran dan inovasi serta keterampilan hidup dan karir (P21, 2015). Framework ini juga menjelaskan tentang keterampilan, pengetahuan dan keahlian yang harus dikuasai agar siswa dapat sukses dalam kehidupan dan pekerjaanya (Sopian, 2016).

Kemdikbud dalam Sopian (2016), menjelaskan bahwa paradigma pembelajaran abad 21 menekankan pada kemampuan siswa dalam mencari tahu dari berbagai sumber, merumuskan permasalahan, berpikir analitis dan kerjasama serta berkolaborasi dalam menyelesaikan masalah. Siswa menjadi pusat utama dari keterlaksanaan proses pembelajaran, sehingga pembelajaran berpusat kepada peserta siswa (Student Centered Learning), dan tidak berpusat pada guru (Teacher Centered Learning). Keterlaksanaan pembelajaran yang berpusat pada siswa (Student Centered Learning) akan menghasilkan pembelajaran yang lebih bermakna karena siswa dituntut tidak hanya untuk mengerjakan tugas saja, tetapi juga memahami tugas-tugas yang sudah dikerjakan dan terbiasa dalam membuat perencanaan tentang materi yang harus mereka pelajari.

Akan tetapi masalah yang kini dihadapi dalam kegiatan pembelajaran di sekolah adalah pemahaman konsep siswa yang masih rendah. Salah satu penyebabnya adalah model pembelajaran guru yang masih bersifat konvensional, yaitu guru lebih banyak menggunakan metode ceramah, dan siswa hanya diam mendengarkan, kemudian kegiatan pembelajaran ditutup dengan tugas-tugas yang diberikan dan tugas-tugas tersebut dikerjakan oleh siswa tanpa siswa memahami secara baik maksud dan tujuan dari tugas-tugas tersebut dan tugas yang dikerjakan tersebut tidak bisa memberikan umpan balik yang positif bagi siswa, sehingga pada pertemuan selanjutnya, siswa akan mudah melupakan konsep-konsep penting pada materi yang telah dipelajari, sehingga pembelajaran menjadi kurang bermakna.

Model pembelajaran yang dipilih untuk memperbaiki kemampuan metakognitif dan pemahaman konsep siswa adalah model pembelajaran inkuiri terbimbing yang dilakukan secara berkelompok dan model pembelajaran kooperatif tipe Teams Games Tournament (TGT). Menurut Llewellyn (2002), model pembelajaran inkuiri memiliki tiga langkah dasar yaitu mengajukan pertanyaan, merencanakan prosedur dan memformulasikan hasil. Proses pengajuan pertanyaan dan merencanakan prosedur sejalan dengan self planning. Proses pembelajaran yang dilakukan secara mandiri tersebut diharapkan mampu meningkatkan self monitoring siswa. Saat siswa memformulasikan hasil dari pembelajaran yang telah dilakukan, diharapkan siswa menyadari materi yang belum dipahami dan mengerti mengapa materi tersebut belum dipahami, serta menyadari kesalahan yang dilakukannya dalam proses pengajuan pertanyaan atau perencanaan prosedur sehingga siswa dapat melakukan self evaluation. 
Sesuai dengan pernyataan Parkay dan Stanfold (2006) bahwa pada pembelajaran inkuiri, siswa diberikan kesempatan untuk bertanya mengenai pokok persoalan sehingga mereka menemukan pengetahuan untuk dirinya sendiri. Pada pembelajaran inkuiri, guru meminta siswa untuk mendapatkan informasi, membuat hubungan antar konsep, serta menyimpulkan atau membentuk suatu generalisasi (Parkay dan Stanfold, 2006). Hal tersebut yang mendasari digunakannya mind map dalam penelitian ini. Mind map adalah alat multi indera visuospatial yang menggunakan orientasi untuk mengintegrasikan informasi dan dapat membantu siswa mengatur dan menyimpan informasi (D'Antoni, Zipp, dan Olson, 2009), sehingga model pembelajaran inkuiri dengan menggunakan mind map diharapkan dapat meningkatkan pemahaman konsep siswa.

Pembelajaran kooperatif tipe TGT merupakan salah satu tipe atau model pembelajaran kooperatif yang melibatkan semua siswa tanpa harus ada perbedaan status, melibatkan peran siswa sebagai tutor sebaya, dan mengandung unsur permainan. Proses belajar dengan permainan yang dirancang dalam pembelajaran kooperatif tipe TGT memungkinkan siswa dapat belajar lebih rileks di samping menumbuhkan tanggung jawab, persaingan sehat, dan keterlibatan belajar. Dengan cara diskusi dalam kelompok seperti pada TGT, siswa akan lebih mudah menemukan dan memahami konsep-konsep yang sulit, sehingga akan meningkatkan pemahaman konsep siswa (Situmorang, 2013).

Berdasarkan hasil penelitian dari Adi, L. Pt, M. R, dkk (2013), menunjukkan bahwa kelompok siswa yang belajar mengikuti model pembelajaran inkuiri terbimbing berbantuan teknik peta konsep menunjukkan pemahaman konsep yang lebih baik dibandingkan dengan kelompok siswa yang belajar mengikuti model pembelajaran konvensional. Hasil penelitian Situmorang (2013), menunjukkan bahwa rata-rata pemahaman konsep matematis siswa hasil pembelajaran kooperatif tipe Teams Games Tournament (TGT) lebih tinggi dari rata-rata pemahaman konsep matematis siswa hasil pembelajaran konvensional. Hal ini berarti penerapan model pembelajaran kooperatif tipe Teams Games Tournament (TGT) berpengaruh positif terhadap pemahaman konsep siswa.

Berdasarkan latar belakang di atas, maka tim peneliti merasa tertarik untuk mengadakan penelitian dengan judul "Pengaruh Model Pembelajaran Inkuiri Terbimbing Dengan Mind Map dan Kooperatif tipe TGT terhadap Pemahaman Konsep Siswa.

Tujuan dilaksanakannya penelitian ini yaitu untuk melihat adanya pengaruh model pembelajaran inkuiri terbimbing dengan mind map dan kooperatif tipe TGT terhadap pemahaman konsep siswa.

\section{METODE}

\section{Rancangan Penelitian}

Penelitian ini merupakan eksperimen semu atau kuasi eksperimen karena tidak semua variabel dan kondisi eksperimen dapat diukur dan dikontrol secara ketat. Subjek dalam penelitian ini adalah siswa kelas VII SMPK St. Yoseph Noelbaki Tahun Ajaran 2015/2016. Perlakuan diberikan pada dua kelas yaitu kelas VII A diberi pembelajaran Inkuiri Terbimbing dengan Mind map, kelas VII B diberi pembelajaran dengan model pembelajaran kooperatif tipe Teams Games Tournament (TGT). Rancangan penelitian disajikan pada Tabel 1. Penelitian ini terdiri dari variabel bebas dan variabel terikat. Variabel bebas dalam penelitian 
ini adalah model pembelajaran inkuiri terbimbing dengan mind map dan model pembelajaran kooperatif tipe TGT, sedangkan variabel terikat adalah pemahaman konsep siswa.

Tabel 1. Rancangan Penelitian

\begin{tabular}{clccc}
\hline No. & \multicolumn{1}{c}{ Pembelajaran } & Pretest & Perlakuan & Posttest \\
\hline 1 & $\begin{array}{l}\text { Inkuiri } \\
\text { dengan Mind map }\left(\mathrm{A}_{1}\right)\end{array}$ & $\mathrm{O} 1$ & $\mathrm{X} 1$ & $\mathrm{O} 2$ \\
\hline 2 & Kooperatif tipe TGT & $\mathrm{O} 1$ & $\mathrm{X} 2$ & $\mathrm{O} 2$ \\
\hline
\end{tabular}

Keterangan:

$\mathrm{O} 1=$ nilai pre test

$\mathrm{O} 2=$ nilai post tes

$\mathrm{X} 1=$ perlakukan inkuri dengan mind map

$\mathrm{X} 2$ = perlakuan model pembelajaran kooperatif tipe Teams Games Tournament (TGT)

\section{Populasi dan Sampel}

\section{Populasi}

Populasi dalam penelitian ini adalah siswa kelas VII SMPK St. Yoseph Noelbaki Tahun Ajaran 2015-2016.

\section{Sampel}

Sampel dalam penelitian ini diambil secara cluster random sampling untuk menentukan kelas yang akan digunakan. Kelas yang digunakan adalah kelas VII A dan VII B. Berdasarkan survei, jumlah siswa kelas VII A sebanyak 34 orang dan siswa kelas VII B sebanyak 31 orang. Kelas yang dijadikan sampel penelitian adalah kelas yang terdiri dari siswa dengan kemampuan akademik tinggi, sedang, dan rendah.

\section{Perangkat Pembelajaran}

Perangkat pembelajaran dalam penelitian ini terdiri atas: Silabus dan Rencana Pelaksanaan Pembelajaran (RPP). Pengembangan silabus mengacu pada kurikulum yang ada di SMPK St. Yoseph Noelbaki. Komponen-komponen yang ada dalam silabus meliputi: standar kompetensi, kompetensi dasar, materi pokok, indikator, pengalaman belajar, penilaian, alokasi waktu, serta alat/bahan dan sumber belajar.

Rencana Pelaksanaan Pembelajaran (RPP) yang dikembangkan dalam dua bentuk yaitu RPP untuk kelas yang diajar dengan model pembelajaran inkuiri terbimbing dengan mind map dan RPP untuk kelas yang diajar dengan model pembelajaran kooperatif tipe Teams Games Tournament (TGT).

\section{Instrumen Penelitian}

Instrumen yang digunakan untuk mengukur pengaruh variabel bebas terhadap variabel terikat dalam penelitian ini adalah rubrik penilaian pemahaman konsep siswa.

\section{Prosedur Pengumpulan Data}

Prosedur pengumpulan data dalam penelitian ini melalui tahap-tahap sebagai berikut: 
1. Pretest

Pretes dilakukan melalui tes tertulis dan dilaksanakan sebelum penerapan model pembelajaran inkuiri terbimbing dengan mind map dan model pembelajaran kooperatif tipe Teams Games Tournament (TGT).

2. Posttest

Postes dilakukan melalui tes tertulis dan dilaksanakan setelah penerapan model pembelajaran inkuiri terbimbing dengan mind map dan model pembelajaran kooperatif tipe Teams Games Tournament (TGT).

\section{Analisis Data}

Data hasil penelitian akan dianalisis dengan statistik inferensial dan deskriptif. Data dianalisis untuk menguji hipotesis dengan menggunakan analisis variansi satu arah (One Way-Anova). Analisis statistik ini dibantu dengan program analisis statistik SPSS 20,0 for Windows, dilakukan dengan taraf signifikansi 5\% $(0,05)$.

\section{HASIL DAN PEMBAHASAN}

\section{Hasil}

Pengelompokkan skor pemahaman konsep siswa dilakukan menurut Green (2007) dalam Bahri (2010). Berdasarkan pengelompokkan ini, maka skor 0 - 20 dikategorikan masih sangat berisiko, 21 - 40 kategori belum begitu berkembang, 41 - 60 kategori mulai berkembang, 61 - 80 kategori berkembang baik, dan 81 - 100 kategori berkembang sangat baik.

Berdasarkan hasil perhitungan dapat dijelaskan bahwa skor rata-rata pemahaman konsep siswa sebelum kegiatan pembelajaran pada kelompok subyek dengan menggunakan model pembelajaran inkuiri terbimbing dengan mind map, dan kelompok subyek dengan menggunakan model pembelajaran kooperatif tipe Teams Games Tournament (TGT) berada pada kategori belum begitu berkembang. Rata-rata skor pemahaman konsep siswa (pretest dan posttest) dapat dilihat pada Tabel 2.

Tabel 2. Rata-rata Skor Pemahaman Konsep Siswa

\begin{tabular}{clcccc}
\hline No. & Variabel Pembelajaran & Pretest & Kategori & Posttest & Kategori \\
\hline 1. & $\begin{array}{l}\text { Inkuiri Terbimbing dengan } \\
\text { Menggunakan Mind Map }\end{array}$ & 37,64 & $\mathrm{Bbb}$ & 58,09 & $\mathrm{Mb}$ \\
\hline 2. & $\begin{array}{l}\text { Teams Games Tournament } \\
\text { (TGT) }\end{array}$ & 26,17 & $\mathrm{Bbb}$ & 50,08 & $\mathrm{Mb}$ \\
\hline
\end{tabular}

Keterangan:

Msb: Masih sangat beresiko

Bbb : Belum begitu berkembang

$\mathrm{Mb}$ : Mulai berkembang

$\mathrm{Bb}$ : Berkembang baik

Bsb : Berkembang sangat baik 
Sementara itu, rata-rata skor pemahaman konsep siswa sesudah kegiatan pembelajaran pada kelompok subyek dengan menggunakan model pembelajaran inkuiri terbimbing dengan mind map, dan kelompok subyek dengan menggunakan model pembelajaran kooperatif tipe Teams Games Tournament (TGT) berada pada kategori mulai berkembang. Tabel 2 di atas memberikan gambaran bahwa pemahaman konsep siswa meningkat sesudah kegiatan pembelajaran.

\section{Uji Hipotesis}

\section{Uji Normalitas Data}

Sebagai persyaratan analisis kovarians, terlebih dahulu dilakukan uji asumsi untuk mengetahui normalitas kelompok data dari masing-masing variabel data. Analisis normalitas data dilakukan dengan menggunakan uji statistik nonparametrik One Sample KolmogrovSmirnov. Hasil uji normalitas terhadap data kelompok subyek yang diajarkan dengan model pembelajaran inkuiri terbimbing dengan mind map dan kelompok subyek yang diajarkan dengan model pembelajaran kooperatif tipe Teams Games Tournament (TGT) menunjukkan bahwa nilai probabilitas (sig.) adalah 0,200 (pemahaman konsep). Nilai probabilitas (sig.) 0,200 tersebut lebih besar dari nilai alpha yang digunakan yaitu 0,05 ; sehingga dapat dikatakan bahwa data berdistribusi secara normal atau dengan kata lain tidak terjadi penyimpangan terhadap normalitas data setiap variabel bebas (model pembelajaran inkuiri terbimbing dengan mind map dan model pembelajaran kooperatif tipe Teams Games Tournament (TGT)), sehingga data variabel terikat (pemahaman konsep) dinyatakan berdistribusi normal.

\section{Uji Homogenitas}

Uji homogenitas data dilakukan terhadap data terkoreksi dari setiap kelompok data penelitian yaitu rata-rata skor data pemahaman konsep. Hasil perhitungan uji homogenitas antar varian yang dilakukan dengan teknik statistik Leven's Test of Equality of Error Variances terhadap variabel terikat (pemahaman konsep) menunjukkan bahwa nilai probabilitas (sig.) adalah 0,320 lebih besar dari nilai alpha yang digunakan yaitu 0,05 . Hal ini menyatakan bahwa $\mathrm{HO}$ diterima, artinya tidak ada perbedaan varian antar kelompok data sehingga data variabel terikat dinyatakan homogen.

Berdasarkan hasil pengujian normalitas dan homogenitas data terlihat bahwa kelompok data variabel pemahaman konsep memiliki distribusi data yang normal dan varian antar kelompok data adalah homogen. Dengan demikian, maka data-data hasil penelitian telah memenuhi syarat untuk dianalisis dengan statistik parametrik, yaitu analisis statistik Anova Satu Arah (One Way-Anova).

\section{Pengaruh Model Pembelajaran Inkuiri Terbimbing dengan Mind Map dan Kooperatiftipe TGT terhadap Pemahaman Konsep}

Data hasil pengukuran terhadap pemahaman konsep siswa dianalisis dengan menggunakan teknik analisis statistik Anova Satu Arah (One Way-Anova) untuk mengetahui pengaruh penerapan model pembelajaran inkuiri terbimbing dengan mind map dan model pembelajaran kooperatif tipe Teams Games Tournament (TGT) terhadap pemahaman konsep siswa. Hasil analisis statistik Anova Satu Arah (One Way-Anova) dapat dilihat pada Tabel 3. 
Tabel 3. Hasil Analisis Statistik Anova Satu Arah

\begin{tabular}{|l|r|r|r|r|r|}
\hline & \multicolumn{1}{|c|}{$\begin{array}{c}\text { Sum of } \\
\text { Squares }\end{array}$} & df & Mean Square & F & Sig. \\
\hline Between Groups & 5724.973 & 1 & 5724.973 & 13.100 & .001 \\
Within Groups & 27094.965 & 62 & 437.016 & & \\
Total & 32819.938 & 63 & & & \\
\hline
\end{tabular}

Hasil analisis varians satu arah (One Way-Anova) pada Tabel 3 menunjukkan bahwa ada pengaruh signifikan pada penerapan model pembelajaran inkuiri terbimbing dengan mind map dan model pembelajaran kooperatif tipe Teams Games Tournament (TGT) terhadap pemahaman siswa. Data hasil analisis pada Tabel 3 menunjukkan bahwa nilai probabilitas (sig.) sebesar 0,01. Nilai ini lebih kecil dari nilai alpha yang ditetapkan yaitu sebesar 0,05, sehingga $\mathrm{H} 0$ yang menyatakan "tidak ada pengaruh penerapan model pembelajaran inkuiri terbimbing dengan mind map dan model pembelajaran kooperatif tipe Teams Games Tournament (TGT) terhadap pemahaman konsep siswa" ditolak dan konsekuensinya hipotesis penelitian yang menyatakan bahwa "adanya pengaruh penerapan model pembelajaran inkuiri terbimbing dengan mind map dan model pembelajaran kooperatif tipe Teams Games Tournament (TGT) terhadap pemahaman konsep siswa" diterima. Dengan demikian, dapat disimpulkan bahwa penerapan model pembelajaran inkuiri terbimbing dengan mind map dan model pembelajaran kooperatif tipe Teams Games Tournament (TGT) menyebabkan adanya perbedaan terhadap pemahaman konsep siswa.

\section{Pembahasan}

Berdasarkan hasil analisis varians satu arah (One Way-Anova) yang menunjukkan bahwa ada pengaruh signifikan pada penerapan model pembelajaran inkuiri terbimbing dengan mind map dan model pembelajaran kooperatif tipe Teams Games Tournament (TGT) terhadap pemahaman siswa sesuai dengan yang dikemukakan oleh Kuhlthau (2010) yang menyatakan bahwa model pembelajaran inkuiri terbimbing dengan mind map memungkinkan siswa untuk memperoleh kedalaman pemahaman dan perspektif pribadi melalui berbagai sumber informasi. Dengan demikian, melalui penerapan model pembelajaran inkuiri terbimbing dengan mind map dapat meningkatkan pemahaman konsep siswa terhadap materi yang telah dipelajari.

Terbimbing dalam konteks ini berarti guru tidak melepaskan sepenuhnya kegiatan pembelajaran kepada siswa melainkan guru menyediakan bantuan apabila siswa menemui hambatan selama kegiatan pembelajaran berlangsung. Bimbingan atau panduan yang diberikan guru melalui beberapa pertanyaan akan membantu memperkecil rasa frustrasi siswa sambil mempertahankan tantangan intelektual tingkat tinggi selama kegiatan inkuiri.

Peningkatan pemahaman konsep siswa berdasarkan hasil analisis statitik juga didukung dengan pernyataan Karakuyu (2010) yang menyatakan bahwa peta konsep dapat digunakan dalam proses pembelajaran untuk menghindari terjadinya belajar menghafal. Dimana dalam pemahaman konsep, siswa diajar dan dilatih untuk memahami konsep-konsep penting terhadap materi-materi yang telah dipelajari dan tidak hanya sekedar kegiatan menghafal materi saja. Selain itu, menurut Villalon \& Calvo (2011) menyatakan bahwa mind 
map (peta konsep) bermanfaat bagi guru yaitu sebagai alat penilaian cepat terhadap pemahaman konseptual siswa. Peta konsep memberikan gambaran ringkas struktur pengetahuan yang ada di kognitif siswa. Jika model pembelajaran inkuiri dapat disinergikan dengan teknik peta konsep sebagai strategi yang memiliki banyak fungsi dan secara umum menunjang kebermaknaan belajar, maka dapat memperdalam pemahaman konsep siswa terhadap suatu materi dalam pelajaran IPA.

Hasil penelitian yang dilakukan oleh Devi, R.S, dkk (2015) juga memperlihatkan adanya peningkatan pemahaman konsep IPA siswa yang memperoleh pembelajaran dengan metode mind mapping lebih baik daripada siswa yang memperoleh pembelajaran biasa. Hal tersebut ditunjukkan melalui pengujian statistik, bahwa terdapat perbedaan rata-rata gain pada kedua kelompok secara signifikan sebesar 0,000. Selain itu, pembelajaran mengunakan mind map mendapat respon yang sangat baik dari siswa. Berdasarkan hasil penelitian Julisyastuti, I.A, dkk (2014) menunjukkan bahwa penerapan mind map dapat dijadikan salah satu alternatif untuk mengatasi rendahnya pemahaman konsep alat peredaran darah pada siswa kelas V SDN Paulan Kecamatan Colomadu Kabupaten Karanganyar Tahun Ajaran $2013 / 2014$.

Menurut Gunawan (2003), mind map juga merupakan cara mencatat yang kreatif, efektif, dan secara harfiah akan memetakan pikiran. Mind map dapat digunakan untuk menyusun fakta dan pikiran sedemikian rupa sehingga cara kerja alami otak dilibatkan sejak awal. Hal ini didasari hasil riset bahwa cara otak mengolah informasi tidak secara linier, setahap demi setahap, tetapi otak menyimpan informasi dan memproses informasi secara acak dan dalam bentuk gambar, bukan dalam bentuk huruf atau tulisan. Dengan demikian, melalui penerapan model pembelajaran inkuiri terbimbing dengan mind map dapat meningkatkan pemahaman konsep siswa.

Demikian halnya dengan model pembelajaran kooperatif tipe Teams Games Tournament (TGT), dimana Teams Games Tournament (TGT) merupakan salah satu tipe atau model pembelajaran kooperatif yang melibatkan semua siswa tanpa harus ada perbedaan status, melibatkan peran siswa sebagai tutor sebaya, dan mengandung unsur permainan. Proses belajar dengan permainan yang dirancang dalam pembelajaran kooperatif tipe TGT memungkinkan siswa dapat belajar lebih rileks di samping menumbuhkan tanggung jawab, persaingan sehat, dan keterlibatan belajar. Dengan cara diskusi dalam kelompok seperti pada TGT, siswa akan lebih mudah menemukan dan memahami konsep-konsep yang sulit, sehingga akan meningkatkan pemahaman konsep siswa (Situmorang, 2013).

Hasil penelitian Situmorang (2013), menunjukkan bahwa rata-rata pemahaman konsep matematis siswa hasil pembelajaran kooperatif tipe Teams Games Tournament (TGT) lebih tinggi dari rata-rata pemahaman konsep matematis siswa hasil pembelajaran konvensional. Hal ini berarti penerapan model pembelajaran kooperatif tipe TGT berpengaruh positif terhadap pemahaman konsep siswa dan mendukung hasil penelitian ini.

\section{KESIMPULAN DAN SARAN}

\section{Kesimpulan}

Berdasarkan hasil analisis data dan pembahasan, dapat disimpulkan bahwa terdapat pengaruh penerapan model pembelajaran inkuiri terbimbing dengan mind map dan model 
pembelajaran kooperatif tipe Teams Games Tournament (TGT) terhadap pemahaman konsep siswa.

\section{Saran}

Saran yang dapat diberikan oleh tim peneliti sebagai refleksi dari pelaksanaan penelitian ini adalah sebagai berikut:

1. Sebaiknya di dalam pelaksanaan model pembelajaran inkuiri terbimbing dengan mind map perlu diperhatikan alokasi waktu yang ada dengan baik, karena model pembelajaran inkuiri terbimbing dengan mind map terdiri dari berbagai langkah-langkah pembelajaran yang cukup banyak dan memerlukan alokasi waktu yang lama, sehingga jika tidak ada perencanaan alokasi waktu yang baik, maka kegiatan pembelajaran dengan model ini akan terhambat.

2. Pengajar perlu menerapkan berbagai model pembelajaran inovatif dan kreatif lainnya sehingga dapat lebih meningkatkan pemahaman konsep siswa, disamping kemampuan dan keterampilan lain yang diharapkan dapat dimiliki oleh siswa, seperti kemampuan dan keterampilan berpikir kritis.

\section{DAFTAR RUJUKAN}

Adi, L. Pt, M. R, dkk. (2013). Pengaruh Model Pembelajaran Inkuiri Terbimbing Berbantuan Teknik Peta Konsep Terhadap Pemahaman Konsep IPA Siswa Kelas V SD di Desa Kaliasem. e-journal. Retrievd from ejournal.undiksha.ac.id/index.php/JJPGSD/article/download/794/667

Anderson, O.W. \& Krathwohl, D.R., (2001). A Taxonomy for Learning, Teaching, and Assessing (A Revision of Bloom's Taxonomy of Educational Objectives). New York: Addision Wesley Longman, Inc.

Anderson, L. W., \& Krathwohl, D. R. (2002). A taxonomi flearning teaching and assessing: A revision of blooms taxonomy educational. New York: Addision Wesley Longman, Inc.

Aprilisa, E. (2012). Tesis. Penerapan Model Pembelajaran Inkuiri Menggunakan Mind map Untuk Meningkatkan Metakognitif Dan Hasil Belajar Siswa Kelas X-1 SMA Negeri 7 Malang. Malang: Universitas Negeri Malang

Binti. (2016). Teams Games Tournament (TGT). Retrieved from https://www.academia.edu/3840575/TEAMS_GAMES_TOURNAMENTS_TGT_A. PENGERTIAN_TEAMS_GAMES_TOURNAMENTS

Depdiknas. (2005). Pendidikan Berorientasi Kecakapan Hidup (Life Skill) melalui Pendekatan Broad-Based Education (BBE). Jakarta: Tim Broad-Based Education Depdiknas.

Devi, R.S, dkk. (2015). Efektivitas Metode Mind mapping Terhadap Peningkatan Pemahaman Konsep Siswa Pada Mata Pelajaran IPA. Jurnal Antologi UPI. Volume 3 Edisi No. 2, Agustus 2015. Retrieved from kdcibiru.upi.edu/jurnal/index.php/antologipgsd/article/view/328

Juliyastuti, I.A., dkk. (2014). Penerapan Mind map untuk Meningkatkan Pemahaman

Konsep Alat Peredaran Darah Pada Peembelajaran IPA. Junal FKIP UNS, Vol 2, No

6. Retrieved from jurnal.fkip.uns.ac.id > Home > Vol 2, No 6 (2014) > Sadiman 
Karakuyu, Y. (2010). The effect of concept mapping on attitude and achievement in a physics course. International Journal of The Physical Sciences, 5(6): 724-737. Retrieved from www.academic journals.org/ijps/PDF/pdf2010/Jun/ Karakuyu.pdf

Kuhlthau, C. C. (2010). Guided inquiry: School libraries in the $21^{\text {st }}$ century. School Libraries Worldwide, 16(1): 17-28. Retrieved from http:// comminfo.ruters.edu/ kuhlthau/doc s/GI-School-Librarians-in-the-21-Century.pdf

Purwanto, N. (2004). Prinsip-prinsip dan teknik: Evaluasi pengajaran. Bandung: Remaja Rosdakarya

Rosyidah, Z. dkk. (2015). Pengaruh Pola Pemberdayaan Berpikir Melalui Pertanyaan dalam Pembelajaran Teams Games Tournament (TGT) terhadap Kemampuan Kognitif, Sikap IPA, dan Kesadaran Metakognitif Siswa. Retrieved from http://journal.um.ac.id/index.php/jps/article/view/4835

Sabiran, NJ. (2013). Model Pembelajaran Inkuiri Terbimbing. Retrieved from http://digilib.unila.ac.id/1033/8/BAB\%20II.pdf

Situmorang, M. dkk. (2013). Pengaruh Penerapan Model Pembelajaran Kooperatif Tipe

Teams Games Tournament (TGT) terhadap Pemahaman Konsep Matematis Siswa.

Retrieved from download.portalgaruda.org/article.php?...PENGARUH\%20PENERAPAN

Sopian, Y. (2016). Pendidikan Abad 21. Retrieved from http://yana.staf.upi.edu/2015/10/11/pendidikan-abad-21/

Sukardi. (2003). Metodologi Penelitian Pendidikan: Kompetensi dan Praktiknya. Yogyakarta: Bumi Aksara

Sukarnan. (2005). Psikologi Kognitif. Surabaya: Penerbit Srikandi

Villalon, J., \& Calvo, R. A. (2011). Concept maps as cognitive visualizations of writing assignments. Educational Technology \& Society, 14(3): 16- 27. Retrieved from www.ifets.info /journals/14_3/3.pdf

Wachidah, U dan Wasis. (2015). Penerapan Strategi Mind mapping Untuk Meningkatkan Keterampilan Metakognitif Siswa Pada Materi Alat-Alat Optik Kelas X SMA Negeri 1 Krembung. Retrieved from http://ejournal.unesa.ac.id/index.php/inovasipendidikan-fisika/article/view/12296 